\title{
A Quantitative Analysis Of AIS Professor Compensation
}

Thomas Tribunella, (E-mail: ttribunella@cob.rit.edu), Rochester Institute of Technology Robert Yeh, (E-mail: yehr@sunyit.edu), SUNY Institute of Technology

\begin{abstract}
Much research has been published related to compensation in major academic fields such as finance and economics, however little attention has been paid to Accounting Information Systems (AIS). Conspicuously absent from the literature are in-depth studies of faculty compensation and its relationship to research productivity for AIS faculty. This study examines compensation, rank and publication data collected from members of the American Accounting Association. Members of the Information Systems section and the Emerging Technology/Artificial Intelligence section were surveyed. The relationships between compensation and its possible determinants such as research productivity and institutional accreditation are reported as well as analyzed. We find that compensation is significantly correlated with professors' profiles as well as the school profile where the professor is employed.
\end{abstract}

\section{INTRODUCTION}

0 productivity and other variables. Some determinants of academic salaries in the field of accounting information systems are suggested.

The Association to Advance Collegiate Schools of Business (AACSB) reports faculty salaries annually in many discipline areas such as finance, accounting, marketing, economics and management. Unfortunately, little is published about the process of evaluating and compensating Accounting Information Systems (AIS) professors. Although many universities have appointment guidelines by rank and experience in promoting and compensating faculty, more factors are often considered to have impacts on faculty salary determination.

This study examines compensation, rank and publication data collected from members of the American Accounting Association (AAA). The relationships among rank, compensation and research productivity could supply valuable insight during promotion, tenure and compensation decisions. The results of this study could benefit professors that teach and research in this interdisciplinary area. In addition, information related to institutional attributes such as accreditation, size, location and degrees conferred are also included in the analysis.

\section{LITERATURE REVIEW AND CONTRIBUTIONS OF THIS STUDY}

\section{Literature Review}

Several journal articles were reviewed to understand previous research conducted in the area of faculty compensation and productivity. A broad range of articles have addressed this issue. Determinants of faculty salaries (Bertin and Zivney, 1992) and rank (Katz, 1973) as well as the value of journal articles published (Tuckman and Leahey, 1975) and citations (Diamond 1986) have been the subject of analysis. For example, Swidler and Goldreuer (1998) reported that a professor's first published article in a top finance journal has a net present value between $\$ 19,493$ and $\$ 33,754$. In another example, Diamond (1986) concluded that the marginal compensation 
value of a citation ranges between $\$ 50$ and $\$ 1,300$. Delorme, Hill, and Wood (1979) took this line of research one step further by conducting a study to analyze quantitative methods of determining faculty salaries. In addition, the earnings and promotion of female faculty has been studied (Johnson and Stafford, 1974b; Cohen, 1971; Ferber, 1974).

Much research has been published related to compensation in major academic fields such as finance (Swidler and Goldreyer, 1998; Vinocur, 1998), the arts and sciences (Katz, 1973), as well as economics (Tuckman and Hagemann, 1976; Melichar, 1965; 1968). Factors which are difficult to control such as congeniality, teaching quality, service to the institution, and journal quality will enter the promotion and compensation process and complicate the analysis (Tuckman and Leahey, 1975). However, some studies have included teaching performance in their analysis (Koch and Chizwar, 1973; Wood and DeLorme, 1976).

Knowledge of an individual's past publication record is an unreliable predictor of future productivity (Zivney and Bertin, 1992). Furthermore, Tuckman and Leahey (1975) as well as Swidler and Goldreuer (1998) reported that publications provide diminishing returns. This may explain why only a small percentage of faculty members remain productive consistently throughout the entire course of their career. For example, many senior faculty members experience a reduction in their research productivity.

\section{Contributions of this Study}

Even though much research has been published related to compensation in major academic fields such as finance and economics, little attention has been given to the area of AIS. Conspicuously absent from the literature are in-depth studies of AIS faculty compensation and its relationship to research productivity. In this study compensation is measured in terms of cash salary. Accordingly, employee benefits, taxes, union contracts, grants, consulting, extra service, and other variables were not taken into consideration.

Since this is the first study of AIS professor compensation it will help administrators, such as department chairs and deans, allocate scarce resources to faculty. It will aid decision processes related to evaluating AIS faculty member salaries. In addition, it may supply information to faculty to help them prioritize their time. Finally, the results may make a contribution to finding a compensation model that is generalizable to other academic fields.

\section{METHODS}

\section{Sample Selection}

In this study AIS professors were surveyed by mail. The sample was taken from members of the AAA Information Systems (IS) section and AAA Artificial Intelligence and Emerging Technology (AI/ET) section. This survey differs from other surveys in that it is seeking to collect data specifically related to the area of AIS and that individuals selected to complete the survey have an interest in the specific field of study. The IS and AI/ET sections of the AAA have many duplicate memberships since these sections serve similar interests. All duplicate names were eliminated from the survey mailing list.

\section{Survey Design}

Each survey was pre-numbered, included a cover letter explaining the purpose of the survey, and a business reply envelope with return postage paid for US mailings.

The respondents were asked to provide compensation information, experience, publications and faculty rank (see Appendix I). Respondents were also asked to supply school and demographic information.

In order to understand the relationship between possible factors and faculty compensation, we first reviewed literature in the area of university faculty compensation. Based on the literature review, we discovered that variables such as rank (Swidler and Goldreyer, 1998), journal publications (Katz, 1973; Delorme et al., 1979; 
Tuckman and Leahey, 1975; Swidler and Goldreyer, 1998; Siegfried and White, 1973), books (Katz, 1973; Siegfried and White, 1973), gender (Katz, 1973; Johnson and Stafford, 1974b), experience (Katz, 1973; DeLorme et al., 1979; Tuckman and Leahey, 1975; Swidler and Goldreyer, 1998; Siegfried and White, 1973; Johnson and Stafford, 1974a), administrative position (Katz, 1973; Tuckman and Leahey, 1975; Swidler and Goldreyer, 1998; Siegfried and White, 1973), school location (Tuckman and Leahey, 1975), and highest degree earned (Katz, 1973; Tuckman and Leahey, 1975), could contribute significantly to a faculty member's compensation. Therefore, we included questions related to these possible factors in our survey.

We also conducted face-to-face interviews with AIS faculty members and department/school administrators to investigate possible factors in determining AIS faculty salary. Individual faculty members were selected on a convenience basis from two universities to pretest the survey. The survey was distributed to five professors who examined and tested the survey for time, clarity, relevance and understandability. The survey was adjusted to incorporate several suggested improvements. The final survey questionnaire was then distributed to collect data.

\section{Statistical Analysis}

The data was collected, coded and entered into SPSS (statistical software package) for analysis. Descriptive statistics were generated so that we could gain an understanding of the data. This was followed by a bivariate correlation test which was conducted between compensation and all possible professor and school factors (Kohler, 2002; Keller, 2003; Hinkle, 1988).

Next, the multivariate contribution of these factors towards faculty compensation is used to analyze the joint impacts of significant factors (Stevens, 1986; Judd et al., 1991). Those variables were entered into four multivariate regression models (overall, assistant professors, associate professors and full professors) following a step-wise sequence. The derived models and their related adjusted $\mathrm{r}$-squares were tested for significance using an $\mathrm{F}$ distribution. Finally, a set of randomly selected observations was excluded from the data used for model building and reserved for checking the validity of the overall compensation model (Frees, 1996).

\section{RESULTS}

\section{Survey Results}

Over 900 members of the Information Systems (IS) section and the Emerging Technology/Artificial Intelligence (ET/AI) section of the AAA were invited to participate in the survey. The response rate for this survey was $17 \%$, which is above the average of five to ten percent according to Alreck and Settle (1995). The response statistics are listed below:

\footnotetext{
- $\quad$ Surveys Mailed: 936

- $\quad$ Surveys Returned on First Request: 102

- $\quad$ Surveys Returned on Second Request: 57

- $\quad$ Total Response Rate: 159 / $936=17.0 \%$

- $\quad$ Usable Surveys: 104

- $\quad$ Usable Response Rate: $104 / 936=11.1 \%$
}

The first survey started in September, 2002 and ended on November 30, 2002. The second request was mailed in February, 2003 with an April 30, 2003 deadline. Faculty members from AACSB accredited schools as well as non-accredited schools are represented. The population of AIS faculty indicating D for computer interests or $\mathrm{S}$ for systems interests listed in Hasselback's (2004) Accounting Faculty Directory is 1,288. Therefore, this data set is an 8.1 percent $(104 / 1,288)$ sample of the population. After the data was collected, it was coded, entered into SPSS (statistical software package) and analyzed. Exhibit 1 shows that 68 percent of the respondents were from AACSB accredited schools. Approximately 87 percent of the respondents were from the United States and approximately 13 percent of the professors are from foreign institutions located in Canada, South America, Asia, Europe and Australia. 


\section{Descriptive Statistics}

Descriptive statistics of schools and respondents are displayed below in Exhibit 1:

EXHIBIT 1

University Profiles Where Respondents Work

\begin{tabular}{|l|c|}
\hline AACSB Status: & Percent \\
\hline Not AACSB Accredited & 32.0 \\
\hline AACSB Accredited & 68.0 \\
\hline Total & 100.0 \\
\hline & \\
\hline Type of College: & Percent \\
\hline Private College & 31.1 \\
\hline Public College & 68.9 \\
\hline Total & 100.0 \\
\hline & \\
\hline College Location: & Percent \\
\hline USA & 87.4 \\
\hline Non-USA & 12.6 \\
\hline Total & 100.0 \\
\hline & \\
\hline Number of Full Time Faculty in Business Division: & Percent \\
\hline 0 to 10 & 4.9 \\
\hline 11 to 20 & 7.8 \\
\hline 21 to 30 & 8.8 \\
\hline 31 to 40 & 13.7 \\
\hline 41 to 50 & 4.9 \\
\hline 51 to 60 & 9.8 \\
\hline 61 to 70 & 9.8 \\
\hline Greater than 70 & 40.3 \\
\hline Total & 100.0 \\
\hline & \\
\hline Business Related Degrees Awarded: & Percent \\
\hline Non-doctorate & 51.5 \\
\hline Doctorate & 48.5 \\
\hline Total & 100.0 \\
\hline
\end{tabular}

As seen in Exhibit 2, approximately 80 percent of the respondents have earned a Ph. D. or DBA. Over 40 percent of the sample held a tenured position and approximately 64 percent of the respondents were either Assistant or Associate Professors. Slightly less than 17 percent of the faculty held the rank of Full Professor. Approximately $66 \%$ percent of the respondents were experienced faculty with six years or more of full time teaching experience.

Exhibit 3 displays a comparison of sampled salaries with AACSB (2003) reported mean salaries by rank. There were no statistically significant differences between the sample data and AACSB averages for assistant and associate professors. This provides evidence that the sample represents the population for assistant and associate professors. However, there was a difference at the full professor rank. It must be noted that our sample of full professors was small and may not be representative of the population. In addition, we sampled only professors with an interest in AIS. The AACSB's data set was larger then our sample and included all interests in the field of accounting. 
EXHIBIT 2

Respondent Profiles

\begin{tabular}{|c|c|c|c|c|}
\hline Faculty Rank: & Percent & $\begin{array}{c}\text { Refereed Journal } \\
\text { Publications: }\end{array}$ & Percent & $\begin{array}{c}\text { Cumulative } \\
\text { Percent }\end{array}$ \\
\hline Adjunct & 1.9 & 0 & 24.5 & 24.5 \\
\hline Lecturer or Instructor & 6.8 & 1 to 3 & 22.9 & 47.4 \\
\hline Assistant & 39.8 & 4 to 6 & 10.4 & 57.8 \\
\hline Associate & 24.3 & 7 to 9 & 8.3 & 66.1 \\
\hline Professor & 16.5 & 10 to 12 & 14.6 & 80.7 \\
\hline Distinguished & 2.9 & 13 to 15 & 5.1 & 85.8 \\
\hline Emeritus & 1.0 & 16 to 18 & 1.0 & 86.8 \\
\hline No Response & 6.8 & 19 to 21 & 4.1 & 90.9 \\
\hline \multirow[t]{5}{*}{ Total } & 100.0 & 22 to 24 & 2.1 & 93.0 \\
\hline & & 25 to 27 & 2.0 & 95.0 \\
\hline & & 28 to 30 & 2.0 & 97.0 \\
\hline & & Greater Than 30 & 3.0 & 100.0 \\
\hline & & Total & 100.0 & \\
\hline Highest Degree Earned: & Percent & Years of Full Time Teaching: & Percent & $\begin{array}{c}\text { Cumulative } \\
\text { Percent }\end{array}$ \\
\hline Bachelor & 1.0 & 0 to 5 & 34.4 & 34.4 \\
\hline Master & 13.6 & 6 to 10 & 20.6 & 55.0 \\
\hline JD or LLM & 0.0 & 11 to 15 & 15.7 & 70.7 \\
\hline ED & 1.0 & 16 to 20 & 12.7 & 83.4 \\
\hline $\mathrm{PhD}$ or $\mathrm{DBA}$ & 80.6 & 21 to 25 & 8.8 & 92.2 \\
\hline No Response & 3.8 & Greater than 25 & 7.8 & 100.0 \\
\hline Total & 100.0 & Total & 100.0 & \\
\hline Tenure Status: & Percent & Gender: & Percent & \\
\hline Non-tenured & 59.2 & Male & 65.3 & \\
\hline Tenured & 40.8 & Female & 34.7 & \\
\hline Total & 100.0 & Total & 100.0 & \\
\hline
\end{tabular}

EXHIBIT 3

AACSB Mean Salaries vs. Sample Mean Salaries

\begin{tabular}{|c|c|c|c|c|c|}
\hline & AASCB & Sample & Difference & $\begin{array}{c}\text { Sample } \\
\text { Size }\end{array}$ & t-test \\
\hline Professor & $\$ 106,900$ & $\$ 93,700$ & $\$ 13,200$ & 14 & $.048^{*}$ \\
\hline Associate & 87,700 & 84,400 & 3,300 & 23 & .525 \\
\hline Assistant & 86,200 & 81,300 & 4,900 & 39 & .138 \\
\hline
\end{tabular}

* Reject the null hypothesis that states the salary means are equal.

\section{Regression Analysis}

Many factors included in our survey were suspected to have impacts on faculty compensation. A bivariate correlation test was conducted between the compensation and all possible factors. Exhibit 4 shows factors that have significant Pearson's correlations with faculty compensation. Among these factors, we see that school characteristics such as AACSB accreditation, degrees offered and geographic location correlate significantly to compensation. In addition, professor profile factors which include earned degrees, publications, rank, teaching experience and tenure also are correlated with compensation. 
EXHIBIT 4

Factors Significantly Correlated with Compensation

\begin{tabular}{|c|c|c|}
\hline & Positive & Negative \\
\hline 0.01 Level: & AACSB accredited & $\begin{array}{c}\text { Non AACSB accredited or AACSB } \\
\text { Candidate }\end{array}$ \\
\hline & Number of published articles & $\begin{array}{c}\text { Instructor rank } \\
\text { Tenure } \\
\text { professional degree }\end{array}$ \\
\hline & Earned Ph.D. degree & \\
\hline & Full-time teaching experience & \\
\hline & School located in USA & \\
\hline & & Adjunct faculty rank \\
\hline & Offers MBA degrees & \\
\hline & USA school & \\
\hline & Full professorship & \\
\hline & Time gap since the degree is earned & \\
\hline
\end{tabular}

After inspecting the bivariate relationship of each factor and the faculty compensation, a function listed as Equation 1 was developed. Equation 1 includes the multivariate contribution of these factors towards faculty compensation and is used to analyze the joint impacts of these factors. Those variables were entered into a multivariate regression model following the step-wise sequence. Furthermore, the model residuals were analyzed to examine the fitness of the model.

Equation 1:

$\mathrm{Y}=\sum_{i=1}^{m} \beta s_{i} X s_{i}+\sum_{j=1}^{n} \beta p_{j} X p_{j}$

Where:

$\mathrm{Y}=$ Faculty compensation

$\mathrm{Xs}_{\mathrm{i}}{ }^{\text {'s }}$ are school factors and $\mathrm{Xp}_{\mathrm{j}}{ }^{\text {'s }} \mathrm{s}$ are professor profile factors

While many factors are tested for entering the model, only factors with significant $(\mathrm{p}<.10)$ impacts are included. The linear regression model that was considered a best-fit in representing Equation 1 was found via least square estimation. The resulting multiple regression model is displayed below as Equation 2.

Equation 2:

$Y=\beta_{0}+\beta s_{1} X s_{1}+\beta s_{2} X s_{2}+\beta s_{3} X s_{3}+\beta p_{1} X p_{1}+\beta p_{2} X p_{2}+\beta p_{3} X p_{3}+\beta p_{4} X p_{4}+$ $\beta p_{5} X p_{5}+\beta p_{6} X p_{6}$

Where:

$\mathrm{Xs}_{1}=1$, if the school is AACSB accredited; otherwise $=0$

$\mathrm{Xs}_{2}=1$, if the school is located in the United States; otherwise $=0$

$\mathrm{Xs}_{3}=$ Number of courses assigned to the professor per year

$\mathrm{Xp}_{1}=$ Number of journal articles published by the professor

$\mathrm{Xp}_{2}=$ Number of textbooks published by the professor

$\mathrm{Xp}_{3}=1$, if a master degree is the highest degree the professor has earned; otherwise $=0$ 
$\mathrm{Xp}_{4}=1$, if a bachelor degree is the highest degree the professor has earned; otherwise $=0$

$\mathrm{Xp}_{5}=1$, if the professor is an adjunct professor; otherwise $=0$.

$\mathrm{Xp}_{6}=1$, if the professor is a full professor; otherwise $=0$

From the regression results summarized in Exhibit 5, we first see that nine factors are significant in explaining the variation in faculty compensation. From school-related factors, we notice that AACSB accredited schools offer higher faculty salaries than the non-accredited schools by about $\$ 16,680$. From our sample U.S. schools offer higher compensation than the other nations mentioned above by about $\$ 23,350$. One other factor, course teaching load, has a negative impact on the faculty compensation. The reason could be that teaching schools, where higher teaching loads are required, pay lower compensation than the research schools where lower teaching loads are the norm.

EXHIBIT 5

Regression Factors Explaining Variance in Compensation

\begin{tabular}{|c|c|c|c|c|c|}
\hline $\begin{array}{c}\text { Regression Model Factor from } \\
\text { Equation 2 }\end{array}$ & $\begin{array}{c}\text { Explanation of Model } \\
\text { Factor }\end{array}$ & $\begin{array}{c}\text { Estimated } \\
\text { Coefficient }\end{array}$ & $\begin{array}{c}\text { Standard } \\
\text { Error }\end{array}$ & t-test & Significance \\
\hline$\beta_{0}$ & Constant & 52,077 & 8,168 & 6.38 & 0.000 \\
\hline$\beta s_{1}$ & AACSB & 16,680 & 5,578 & 2.99 & 0.004 \\
\hline$\beta s_{2}$ & USA & 23,359 & 7,672 & 3.05 & 0.003 \\
\hline$\beta s_{1}$ & Course Load & $-2,499$ & 989 & -2.53 & 0.014 \\
\hline$\beta p_{1}$ & Published Articles & 945 & 273 & 3.45 & 0.001 \\
\hline$\beta p_{2}$ & Published Books & 925 & 521 & 1.78 & 0.080 \\
\hline$\beta p_{3}$ & Master's Degree & $-28,603$ & 7,067 & -4.05 & 0.000 \\
\hline$\beta p_{4}$ & Bachelor's Degree & $-65,866$ & 19,138 & -3.44 & 0.001 \\
\hline$\beta p_{5}$ & Adjunct Professor & $-44,187$ & 19,102 & -2.31 & 0.024 \\
\hline$\beta p_{6}$ & Full Professor & 13,488 & 6,993 & 1.93 & 0.058 \\
\hline
\end{tabular}

Besides the three factors from schools, the remaining significant factors are from professors' profiles. Professors' scholarly outputs play an important role in determining their compensation. According to the regression results, each published journal article increases the author's annual compensation by $\$ 945$, while each published book increases the annual compensation by $\$ 925$. Although these may seem to be relatively small increments, the accumulated sum over a professor's life-time career can be substantial. Swidler and Goldreuer (1998) have applied this concept in the field of finance by estimating the total net present value of an article in terms of professor compensation.

Another profile factor is the highest degree earned by a professor. In the regression model, where doctoral degree is used as an anchor level for comparison, professors with only master degrees earn approximately $\$ 28,000$ less annually while professors with only bachelor degrees earn even less. Considering all the significant factors including school and professor profile, an earned doctoral degree is the most substantial determinant of salary.

Although professors with all ranks are present in our data, only the adjunct status and full professorships are statistically significant. No obvious difference is detected between assistant professors and associate professors, which serve as the comparison anchor. An adjunct professor makes substantially less, about $\$ 44,000$, and a full professorship adds about $\$ 13,000$ more in the compensation model.

The results from the last factor, professor ranks, lead us to consider whether this compensation model, which is built for all ranks of professors, can also be applied within each rank. Separate models are then built for assistant professors, associate professors, and full professors. Along with the original model, these three models are included in Exhibit 6 for comparison. 
EXHIBIT 6

Regression Models for Compensation by Rank

\begin{tabular}{|c|c|c|c|c|c|c|c|c|}
\hline & \multicolumn{2}{|c|}{$\begin{array}{c}\text { Overall Model } \\
\text { (Equation 2) }\end{array}$} & \multicolumn{2}{|c|}{ Assistant Professors } & \multicolumn{2}{|c|}{ Associate Professors } & \multicolumn{2}{|c|}{ Full Professors } \\
\hline & Coeff. & Sig. & Coeff. & Sig. & Coeff. & Sig. & Coeff. & Sig. \\
\hline Constant & 52,077 & 0.000 & 12,217 & 0.243 & 55,120 & 0.002 & 68,339 & 0.000 \\
\hline AACSB & 16,680 & 0.004 & 25,047 & 0.000 & & & & \\
\hline USA & 23,359 & 0.003 & 25,047 & 0.000 & 31,667 & 0.006 & & \\
\hline Course Load & $-2,499$ & 0.014 & & & & & & \\
\hline Published Articles & 945 & 0.001 & & & 650 & 0.090 & 1,466 & 0.001 \\
\hline Published Books & 925 & 0.080 & & & & & & \\
\hline Master's Degree & $-28,603$ & 0.000 & $-19,811$ & 0.084 & & & & \\
\hline Bachelor's Degree & $-65,866$ & 0.001 & & & & & & \\
\hline Adjunct Professor & $-44,187$ & 0.024 & & & & & & \\
\hline Full Professor & 13,488 & 0.058 & & & & & & \\
\hline Gender & & & 15,283 & 0.001 & & & & \\
\hline Years of Experience & & & & & -644 & 0.125 & & \\
\hline Non-AACSB & & & & & $-31,193$ & 0.002 & & \\
\hline Faculty Size & & & & & 212 & 0.039 & & \\
\hline Number of Observations & \multicolumn{2}{|c|}{80} & \multicolumn{2}{|c|}{39} & \multicolumn{2}{|c|}{23} & \multicolumn{2}{|c|}{14} \\
\hline R-square & \multicolumn{2}{|c|}{0.659} & \multicolumn{2}{|c|}{0.707} & \multicolumn{2}{|c|}{0.799} & \multicolumn{2}{|c|}{0.574} \\
\hline Adjusted R-square & \multicolumn{2}{|c|}{0.616} & \multicolumn{2}{|c|}{0.674} & \multicolumn{2}{|c|}{0.744} & \multicolumn{2}{|c|}{0.541} \\
\hline Model F-test & \multicolumn{2}{|c|}{15.24} & \multicolumn{2}{|c|}{21.123} & \multicolumn{2}{|c|}{14.355} & \multicolumn{2}{|c|}{17.484} \\
\hline F-test Significance & \multicolumn{2}{|c|}{0.000} & \multicolumn{2}{|c|}{0.000} & \multicolumn{2}{|c|}{0.000} & \multicolumn{2}{|c|}{0.001} \\
\hline
\end{tabular}

Compared to Equation 2, which is the compensation model for all professors, models for these three individual ranks include fewer significant factors to account for the variation in their compensations within each group. For assistant professors, we find the positions from AACSB accredited schools offer higher annual compensation by about $\$ 25,000$. Also, assistant professors with only master degrees have lower salaries by about $\$ 19,800$.

Gender is another significant factor in describing the assistant professors' compensation. Instead of interpreting the gender effect in compensation directly, we would like to point out the following findings first. We find, in our data set, gender is highly correlated with several other factors such as publication quantity and time with current jobs. Although, from the current model for assistant professors, it may be interpreted as female assistant professors receive lower compensation than male professors, we reserve our support on this statement due to the high correlation between the gender factor and other factors. We are not implying that women are less productive or less experienced, further research needs to be conducted in this area.

The model for associate professors includes AACSB accreditation, USA regional schools, number of published journal articles, faculty size and years of experience. Similar to the assistant professors' model, a nonAACSB accredited school pays its associate professors lower than an AACSB-accredited school by about $\$ 31,000$. Besides the accreditation, we also find that USA schools offer higher compensation. Number of published journal articles also plays an important role here. Another factor that is not found to be significant in earlier models but is significant in this model is the full-time faculty size. This indicates that larger schools (in faculty size, not student enrollment) pay more than smaller schools. We also found that the time length of an associate professor's duration at his/her employer has a negative impact on compensation. Accordingly, newer associate professors earn higher salaries than their senior associate peers. The model for full professors indicates that the number of published journal articles is the sole significant factors in compensation determination. 


\section{Validity Test of the Compensation Model}

We implemented a validation process by splitting the sample into two data sets, a model building set and a validation set (Neter et al., 1996; Frees, 1996). This procedure is known as cross-validation (Neter et al., 1996). A validation set of twenty-four randomly selected observations (Frees, 1996) was excluded from the data used for model building and reserved for checking the validity of the derived compensation model. Due to the size of this reserved data set, only the overall model, as shown in Equation 2, is being tested. For each professor included in the test set, his/her school factors and professor profile factors are applied in the compensation model in order to find the predicted salary. Comparison results of these twenty-four professors' actual salaries and predicted salaries, along with the difference between the two, are shown in Exhibit 7.

EXHIBIT 7

Comparison of Model Prediction Results and Actual Outcomes

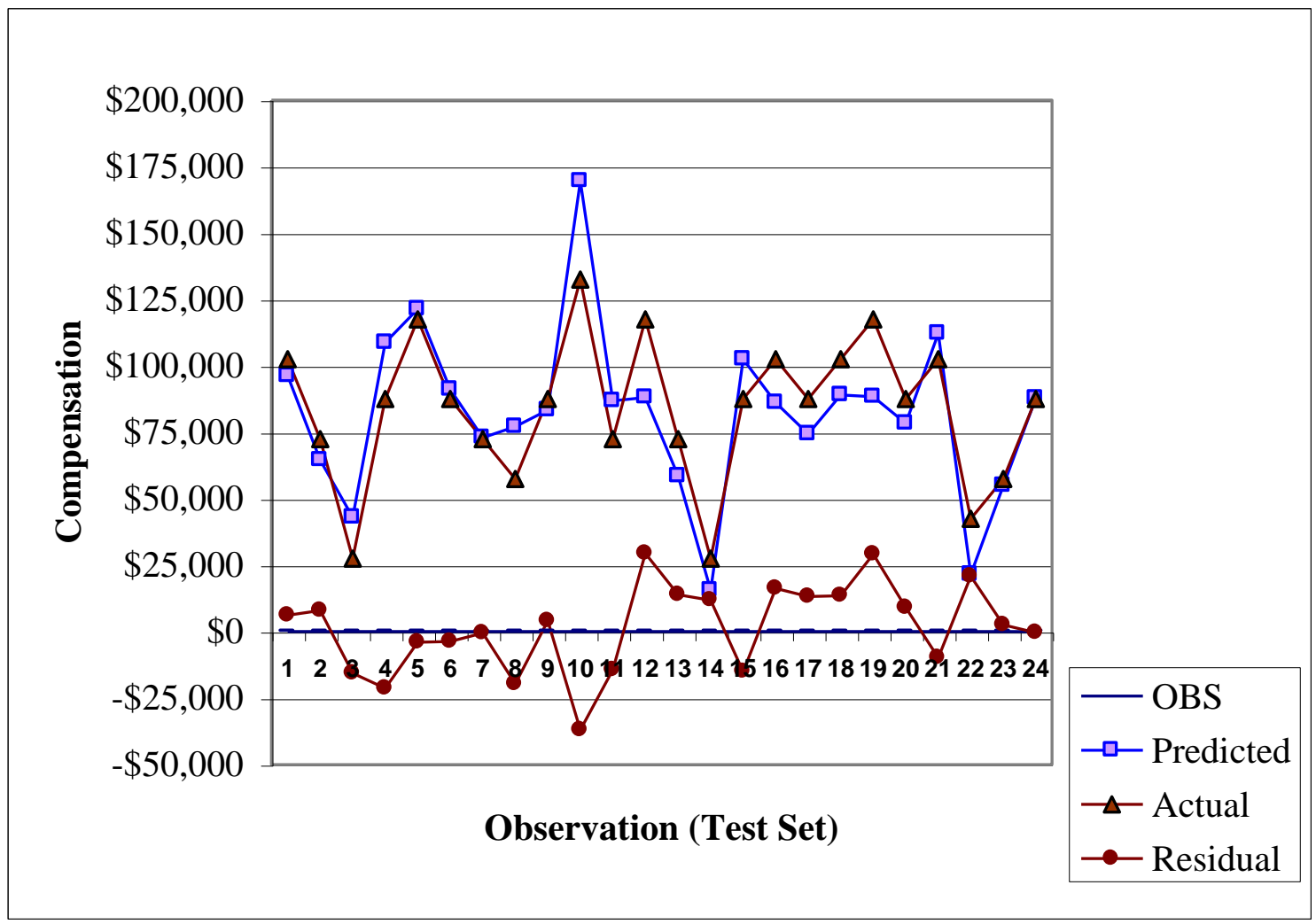

OBS: Observation number

We can see that the predicted outcome from the model is very close to the actual salaries in the validation set. The movement of the actual and the predicted salary lines in Exhibit 7 are highly correlated with each other. The residuals from these twenty-four observations fall within a narrow range. This indicates a professor's salary in the area of AIS can be closely predicted by using his or her school and professor profile factors.

\section{SUMMARY, CONCLUSIONS AND FUTURE RESEARCH}

\section{Summary and Conclusions}

This research took data from a survey of AIS professors and built a model for predicting AIS professor 
salaries. Major factors which contribute to a professor's compensation were detected. The model was tested and found to be a good predictor with low residuals and an adjusted r-square of .616 for the overall model (see Exhibit 6). From our study, besides confirming the impacts of the considered determinants on compensation, heterogeneity in compensation within different faculty ranks is also found. For example, the models for assistant and associate professors produced adjusted r-squares of .674 and .744 respectively (see Exhibit 6). When the AIS model posited in this study is compared to compensation models related to other academic disciplines, many similarities are found (see Exhibit 8).

EXHIBIT 8

Summary of Faculty Compensation Models

\begin{tabular}{|c|c|c|c|c|c|}
\hline Authors & This Study & $\begin{array}{c}\text { Bertin and } \\
\text { Zivney }\end{array}$ & $\begin{array}{l}\text { DeLorme, Hill } \\
\text { and Wood }\end{array}$ & $\begin{array}{c}\text { Siegfried and } \\
\text { White }\end{array}$ & Katz \\
\hline $\begin{array}{c}\text { Usable } \\
\text { Observations }\end{array}$ & 104 & 377 & 49 & 45 & 596 \\
\hline $\begin{array}{c}\text { R-square of } \\
\text { Model }\end{array}$ & $\begin{array}{l}.541 \text { to } .744 \\
\text { (adjusted) }\end{array}$ & .706 (adjusted) & .642 to .707 & .881 & .680 \\
\hline Year of Study & 2004 & 1992 & 1979 & 1973 & 1973 \\
\hline $\begin{array}{l}\text { Disciplines } \\
\text { Analyzed }\end{array}$ & $\begin{array}{l}\text { accounting } \\
\text { information } \\
\text { systems }\end{array}$ & finance & $\begin{array}{l}\text { accounting, } \\
\text { finance, } \\
\text { management, } \\
\text { marketing, real } \\
\text { estate, and } \\
\text { insurance }\end{array}$ & economics & $\begin{array}{c}\text { economics, } \\
\text { engineering, } \\
\text { English, French, } \\
\text { history, math, } \\
\text { physics, political } \\
\text { science, } \\
\text { psychology, } \\
\text { sociology, } \\
\text { zoology }\end{array}$ \\
\hline $\begin{array}{c}\text { Significant } \\
\text { Faculty and } \\
\text { School Factors }\end{array}$ & $\begin{array}{c}\text { course load, } \\
\text { articles, } \\
\text { books, } \\
\text { master's degree, } \\
\text { bachelor's } \\
\text { degree, } \\
\text { adjunct } \\
\text { professor, } \\
\text { full professor, } \\
\text { gender, } \\
\text { experience, } \\
\text { AACSB, USA, } \\
\text { Faculty Size }\end{array}$ & $\begin{array}{l}\text { named position, } \\
\text { full professor, } \\
\text { associate } \\
\text { professor, } \\
\text { presentations, } \\
\text { just promoted, } \\
\text { years with } \\
\text { employer, } \\
\text { articles, public } \\
\text { school, AACSB, } \\
\text { PhD program, } \\
\text { MBA program, } \\
\text { articles for } \\
\text { tenure, state } \\
\text { income tax }\end{array}$ & $\begin{array}{l}\text { publications, } \\
\text { experience, } \\
\text { teaching scores, } \\
\text { department, } \mathrm{PhD} \\
\text { from southern } \\
\text { school }\end{array}$ & $\begin{array}{c}\text { experience, } \\
\text { monographs, } \\
\text { national journal } \\
\text { articles, specialty } \\
\text { journal articles, } \\
\text { other } \\
\text { publications, } \\
\text { teaching scores, } \\
\text { school service }\end{array}$ & $\begin{array}{l}\text { books, articles, } \\
\text { top publications, } \\
\text { dissertations } \\
\text { supervised, } \\
\text { public service, } \\
\text { school service, } \\
\text { experience, } \\
\text { department, rank } \\
\text { of schools } \\
\text { attended, gender, } \\
\text { PhD }\end{array}$ \\
\hline
\end{tabular}

With the AACSB promoting clearer personnel policies we should search for better ways to quantify or measure the productivity of professors. This model could be used to make recommendations to an administration regarding how to compensate AIS faculty during hiring decisions and periodic salary adjustments. For example, a published journal article can justify a salary increase of $\$ 945$ for the author (see Exhibit 6).

The model also provides guidance to AIS faculty regarding career management and how to increase salary. For example, a faculty member can assume that the present value of a journal article for 20 years at four percent is $\$ 12,843$ on average. Therefore, publishing may be more profitable than extra teaching or consulting.

Many of the factors identified by the model such as publications, teaching load and highest degree earned are obvious variables related to compensation. However, this research not only identifies the significant variables, but also produces a quantitative measure of the relevant variables. Moreover, this compensation model should 
augment vague qualitative concepts with a quantitative method of determining salary and promotion decisions.

\section{Limitations of the Study}

Respondents working outside of the US were asked to report their compensation in US dollars. No adjustments were made for the cost of living in the various countries. Therefore, if the cost of living is lower in those countries, then salaries outside of the US may appear to be lower than US salaries.

In this study, compensation is measured in terms of cash salary only. Employee benefits, taxes, union contracts, grants, consulting, extra service, and other variables were not taken into consideration. These factors may contribute significantly to total compensation. Furthermore, these factors may vary significantly from one faculty members to another. This could have a material effect on a compensation model.

In this study, productivity only includes research related inputs such as refereed conference proceedings, journal articles and books. Teaching evaluations and service were not taken into consideration. These items may effect compensation significantly. In addition, the quality of the journal articles was not taken into consideration.

\section{Future Research Questions}

Even though this paper provides an initial investigation, further research would extend the analysis and add to the literature. This section will review a list of questions that could be addressed by future research. First, is AIS faculty compensation positively associated with publications in prestigious AIS journals? How does a tier 1, 2, 3, etc... published journal article impact a faculty members compensation? This study examined the effects on compensation by the quantity of publications but it did not address the quality of publications.

Does the value of publishing drop off at a certain stage of a professor's career or beyond a certain quantity of publications? In other words, are there diminishing returns to publishing? It would be interesting to know if publications received early in one's career have a greater effect on compensation than publications in later years.

In addition, we could ask, are employment mobility and compensation associated due to salary compression? Salary compression occurs when faculty pay raises do not keep pace with the job market. Over a period of time, a faculty member who is not mobile may be compensated significantly under market pay rates.

Questions related to faculty compensation are important. The answers will provide valuable insights to administrators for their resource allocation decisions. Furthermore, faculty should understand their value so they can negotiate a realistic compensation package. Rational and efficient faculty compensation can be an important variable for attracting qualified individuals to academic professions.

\section{Acknowledgements}

We appreciate the insightful comments made by two anonymous reviewers and the participants at the 2004 Northeast Decision Science Institute meeting.

\section{REFERENCES}

1. Association to Advance Collegiate Schools of Business. 2003. AACSB 2002-2003 Salary Survey Executive Summary. (www.aacsb.edu).

2. Alreck, P. L., and R. B. Settle. 1995. The Survey Research Handbook, second edition. (Chicago, IL, Irwin).

3. Bertin, W. J., and T. L. Zivney. 1992. "The Determinants of Finance Faculty Salaries: The 1991-1992 FMA Salary Survey." Financial Practice and Education (Spring/Summer) 19-29.

4. $\quad$ Cohen, M. S. 1971. "Sex Differences in Compensation." The Journal of Human Resources (fall) 434.

5. DeLorme, C. D., R. C. Hill, and N. J. Wood. 1979. "Analysis of a Quantitative Method of Determining Faculty Salaries." The Journal of Economic Education (fall) 20-25. 
6. Diamond, A. M. 1986. "What is a citation worth?” Journal of Human Resources (21) 200-215.

7. $\quad$ Ferber M. A. 1974. "Professors, Performance and Rewards." Industrial Relations (February) 69-77.

8. Frees E. W. 1996. Data Analysis Using Regression Models: The Business Perspective. (Upper Saddle River, NJ. Prentice Hall Business Publishing).

9. Johnson, G. E., and F. P. Stafford. 1974a. "Lifetime Earnings in a Professional Labor Market: Academic Economists." The Journal of Political Economy (May/June) 549-569.

10. Johnson, G. E., and F. P. Stafford. 1974b. "The Earnings and Promotion of Women Faculty." The American Economic Review (December) 888-903.

11. Judd, C. M., E. R. Smith, and L. H. Kidder. 1991. Research Methods in Social Relations. (London, UK, Holt, Rinehart and Winston).

12. Hinkle, D. E., W. Wiersma, and S. G. Jurs. 1988. Applied Statistics for the Behavioral Sciences. (Boston, MA, Houston Mifflin).

13. Katz, D. A. 1973. "Faculty Salaries, Promotions, and Productivity at a Large University." The American Economic Review (June) 469-477.

14. Keller, G., and B. Warrack. 2003. Statistics for Management and Economics, $6^{\text {th }}$ edition. (Pacific Grove, CA, Brooks/Cole - Thomson Learning).

15. Koch, J. V., and J. F. Chizwar. 1973. "The Influence of Teaching and Other Factors Upon Absolute Salaries and Salary Increments at Illinois State University." The Journal of Economic Education (fall) 2734.

16. Kohler, H. 2002. Statistics for Business and Economics. (London, UK, South-Western and Thompson Learning).

17. Hasselback, J. R. 2004. Accounting Faculty Directory 2004-2005. (Upper Saddle River, NJ, Prentice Hall).

18. Melichar, E. 1965. "The Net Influence on Economists' Salaries of each of Seven Characteristics: A Regression Analysis.” American Economic Review (Vol. 55, Dec.) 63-70.

19. Melichar, E. 1968. Factors Affecting 1966 Basic Salaries in the National Register Professions. American Economic Review (Vol. 58, Dec.) 56-79.

20. Neter, J., M. H. Kutner, C. J. Nachtsheim, and W. Wasserman. 1996. Applied Linear Statistical Models, fourth edition. (Chicago, IL, McGraw-Hill/Irwin).

21. Siegfried, J. J., and K. J. White. 1973. "Financial Rewards to Research and Teaching: a Case Study of Academic Economists.” Economic Education (Vol. 63, No. 2, May) 309-316.

22. Stevens, J. 1986. Applied Multivariate Statistics for the Social Sciences. (Hillsdale, New Jersey, Lawrence Erlbaum Associates).

23. Swidler S. and E. Goldreyer. 1998. "The Value of a Finance Journal Publication." The Journal of Finance (February) 351-363.

24. Tuckman, H. P., and J. Leahey. 1975. "What is an Article Worth?” Journal of Political Economy (Vol. 83, No. 51) 951-967.

25. Tuckman, H. P., and R. P. Hagemann. 1976. "An Analysis of the Reward Structure in Two Disciplines." Journal of Higher Education (July/August) 447-464.

26. Wood N. J., and C. D. DeLorme. 1976. "An Investigation of the Relationship Among Teaching Evaluations, Research and Ability." The Journal of Economic Education (spring) 77-80.

27. Vinocur, B. 1998. "Publish or Perish: The Economic Implications." Dow Jones Asset Management (January/February) 53-54.

28. Zivney, T. L., and W. J. Bertin. 1992. "Publish or Perish: What the Competition is Really Doing." The Journal of Finance (March) 295-329. 


\section{APPENDIX I}

\section{Survey Questionnaire}

\section{Instructions and Privacy Statement}

Please enter the appropriate answer in the response column. All individual data collected will be kept strictly confidential. Only summarized results and analyses will be made public. The survey should take about 20 to 30 minutes to complete.

\section{University Information:}

\begin{tabular}{|c|c|}
\hline & Response Column \\
\hline $\begin{array}{l}\text { 1. Is the school of business where you work AACSB accredited? 1) No 2) Candidate for } \\
\text { Accreditation 3) Yes, Fully Accredited }\end{array}$ & \\
\hline $\begin{array}{l}\text { 2. List the business related degrees awarded by your university. 1) Associate 2) } \\
\text { Bachelor 3) Master of Science 4) MBA 5) Doctorate 6) Other, please specify in the } \\
\text { response column }\end{array}$ & \\
\hline $\begin{array}{l}\text { 3. Where is your university's main campus located? } \\
\text { 1) Canada 2) South America 3) Asia 4) Europe 5) Africa 6) Australia 7) USA 8) Internet 9) } \\
\text { Other, please specify in the response column }\end{array}$ & \\
\hline $\begin{array}{l}\text { 4. How many full-time faculty members are employed in the business division at your } \\
\text { university? 1) } 0 \text { to } 10 \text { 2) } 11 \text { to } 20 \text { 3) } 21 \text { to } 304 \text { 4) } 31 \text { to } 40 \text { 5) } 41 \text { to 50 6) } 51 \text { to } 60 \text { 7) } 61 \text { to } 70 \\
\text { 8) Greater than } 70\end{array}$ & \\
\hline $\begin{array}{l}\text { 5. Do you work at a private university or state university? } \\
\begin{array}{lll}\text { 1) Private } & \text { 2) State } & \text { 3) Other, please specify in the response column }\end{array}\end{array}$ & \\
\hline
\end{tabular}




\section{Research Information:}

\begin{tabular}{|c|c|}
\hline \multirow{2}{*}{$\begin{array}{l}\text { 1. How many accounting and business related articles have you published in refereed } \\
\text { journal? }\end{array}$} & Response Column \\
\hline & \\
\hline \multicolumn{2}{|l|}{ 2. How many accounting and business related books have you published? } \\
\hline \multicolumn{2}{|l|}{$\begin{array}{l}\text { 3. How many accounting and business related papers or abstracts have you published } \\
\text { in refereed conference proceedings? }\end{array}$} \\
\hline \multicolumn{2}{|l|}{$\begin{array}{l}\text { 4. What are your } 5 \text { most primary areas of interest in AIS? } \\
\text { 1) Security 2) Database 3) E-commerce 4) ERP Systems 5) Networking 6) System Design } \\
\text { 7) Decision Support 8) Computerized Transaction Processing 9) Auditing EDP Systems } \\
\text { 10) Electronic Reporting 11) Other, please specify in the response column }\end{array}$} \\
\hline \multicolumn{2}{|l|}{$\begin{array}{l}\text { 5. What professional and academic organizations are you a member? 1) AAA 2) } \\
\text { AICPA 3) ACM 4) IEEE 5) DSI 6) CGA Assn. Of Canada 7) Canadian Inst. Of CA 8) } \\
\text { ICAEW 9) Other, please specify in the response column }\end{array}$} \\
\hline \multicolumn{2}{|l|}{$\begin{array}{l}\text { 6. In the spaces below, please list the name of } 3 \text { AIS related journals that you read the } \\
\text { most and are most familiar with. }\end{array}$} \\
\hline \multicolumn{2}{|l|}{ 1) } \\
\hline \multicolumn{2}{|l|}{ 2) } \\
\hline \multicolumn{2}{|l|}{ 3) } \\
\hline \multicolumn{2}{|l|}{$\begin{array}{l}\text { 7. In the spaces below, please list the } 3 \text { most prestigious journals where you have } \\
\text { published AIS related papers and the number of papers published in each journal. }\end{array}$} \\
\hline Journal Name & Number of Papers \\
\hline \multicolumn{2}{|l|}{ 1) } \\
\hline \multicolumn{2}{|l|}{ 2) } \\
\hline 3) & \\
\hline
\end{tabular}


Professional and Compensation Information:

\begin{tabular}{|c|c|}
\hline & Response Column \\
\hline 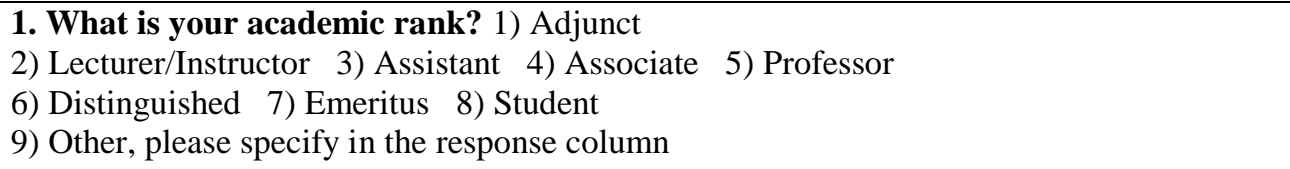 & \\
\hline 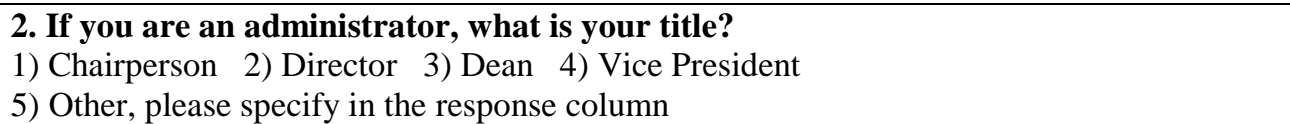 & \\
\hline 3. Do you have tenure? 1) No 2) Yes & \\
\hline 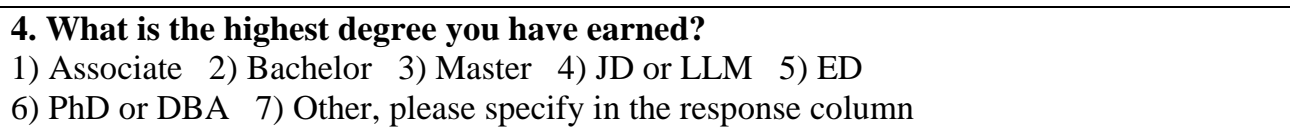 & \\
\hline $\begin{array}{l}\text { 5. How many years ago did you earn your highest degree? } \\
\begin{array}{lllll}\text { 1) } 0 \text { to } 5 & \text { 2) } 6 \text { to } 10 & \text { 3) } 11 \text { to } 15 & \text { 4) } 16 \text { to } 20 & \text { 5) } 21 \text { to } 25\end{array} \\
\text { 6) Greater than } 25\end{array}$ & \\
\hline 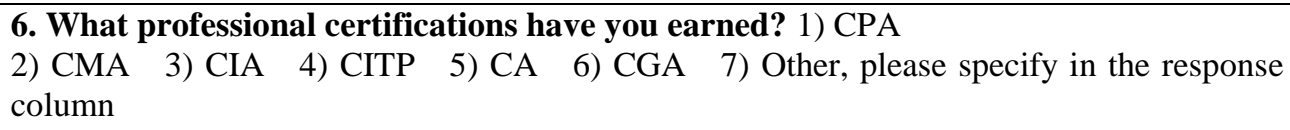 & \\
\hline $\begin{array}{l}\text { 7. What is the base cash compensation you earn per year for your faculty position in } \\
\text { US dollars? (This amount should be limited to compensation before extra service, teaching } \\
\text { overloads, grants, royalties, summer support, benefits, etc...) } \\
\begin{array}{llll}\text { 1) } 0 \text { to } 35,000 & \text { 2) } 35,001 \text { to } 50,000 & \text { 3) } 50,001 \text { to } 65,000 \\
\text { 4) } 65,001 \text { to } 80,000 & \text { 5) } 80,001 \text { to } 95,000 & \text { 6) } 95,001 \text { to } 110,000 \\
\text { 7) } 110,001 \text { to } 125,000 & \text { 8) Greater than } 125,000\end{array}\end{array}$ & \\
\hline 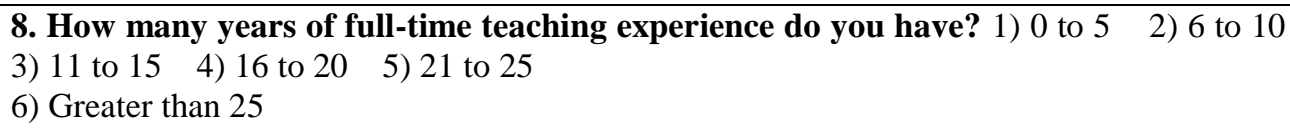 & \\
\hline 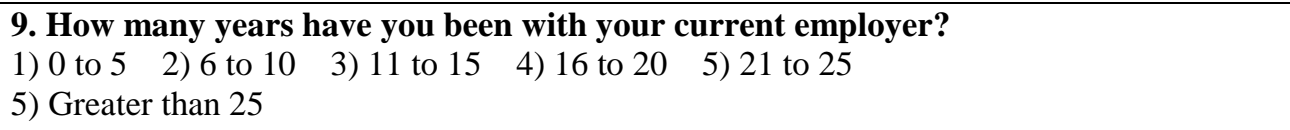 & \\
\hline $\begin{array}{l}\text { 10. What is your required teaching load in course sections per academic year? 1) } 1 \text { to } \\
\begin{array}{llll}2 & \text { 2) } 3 \text { to } 4 & \text { 3) } 5 \text { to } 6 & \text { 4) } 7 \text { to } 8 \\
\text { 5) } 9 \text { to } 10 & \text { 6) } 11 \text { to } 12 & \text { 7) over } 12\end{array}\end{array}$ & \\
\hline
\end{tabular}


Notes 